\title{
Evaluation of the Interaction Between Phytase and Xilanase on Metabolizability of Energy-Reduced Broiler Diets $^{1}$
}

\author{
Natália Ramos Batista Chaves (Corresponding Author) \\ Instituto Federal de Educação, Ciência e Tecnologia do Mato Grosso - Campus Alta Floresta, \\ Brazil. E-mail: natalia.chaves@alf.ifmt.edu.br
}

Karina Marcia Ribeiro de Souza Nascimento, Charles Kiefer, Maurício Silva Rosa, Henrique Barbosa de Freitas, Luanna Lopes Paiva, Thiago Rodrigues da Silva, Violeta Andre Macie Universidade Federal de Mato Grosso do Sul, UFMS, Faculdade de Medicina Veterinária e Zootecnia - Brazil

Elis Regina de Moraes Garcia

Universidade Estadual de Mato Grosso do Sul, Brazil

Larissa Albuquerque Rosa Silva

Universidade Federal de Mato Grosso do Sul, UFMS, Faculdade de Medicina Veterinária e Zootecnia - Brazil

Received: Jan. 15, 2020

doi:10.5296/jas.v8i3.16242
Accepted: Mar. 12, 2020 Published: Apr. 22, 2020

URL: https://doi.org/10.5296/jas.v8i3.16242

\begin{abstract}
To examine the association between phytase and xylanase in diets with nutritional adjustments on the metabolizability of feed by broiler diets, 250 chickens were used and distributed among five treatments and five replicates of 10 broilers each. The treatments were: positive control diet - without phytase or xylanase; negative control diet - with an energy reduction of $0.419 \mathrm{MJ} / \mathrm{kg}$, without phytase or xylanase; and three diets containing xylanase
\end{abstract}

${ }^{1}$ Part of the thesis presented by the first author to the Universidade Federal de Mato Grosso do Sul - UFMS. 
and phytase and energy reductions of $0.209,0.419$ and $0.628 \mathrm{MJ} / \mathrm{kg}$. For all energy-reduced diets, the nutritional matrix of phytase with phosphorus $(0.15 \%)$, calcium $(0.165 \%)$ and sodium $(0.035 \%)$ was considered. The energy reduction of $0.628 \mathrm{MJ} / \mathrm{kg}$ with inclusion of the enzymes resulted in a higher metabolizability of the crude protein, also the apparent and apparent corrected metabolizable energy coefficients for nitrogen balance were higher in diets with a reduction energy of $0.209 \mathrm{MJ} / \mathrm{kg}$, however had values similar to those obtained in the positive control diets and diets with energy reduction of $0.628 \mathrm{MJ} / \mathrm{kg}$ containing enzymes. The inclusion of phytase (500 FTU/kg) and xylanase (16,000 BXU/kg) in broiler diets, makes it possible to reduce metabolizable energy by up to $0.628 \mathrm{MJ} / \mathrm{kg}$, available phosphorus, calcium, and sodium, and improve the metabolizability of the nutrients.

Keywords: Additives, Available phosphorus, Calcium, Carbohydrase, Exogenous enzyme, Non-starch polysaccharides, Phytic acid, Sodium

\section{Introduction}

The modern context in which broiler nutrition is studied makes it possible to formulate diets containing enzymes that are not endogenously produced by broilers, with the objective of improving the metabolizability of nutrients and the utilization of vegetal ingredients acting on the breaking of phytates, soluble and insoluble non-starch polysaccharides (NSPs).

Phytates and NSPs are naturally present in the diet of broilers. It is estimated that the bioavailability of phosphorus is approximately $27.6 \%$ in corn and $37.3 \%$ in soybean meal (Rostagno et al., 2017). Similarly, NSP contents range from 8.1 to $9.7 \%$ in corn and from 10.3 to $30.3 \%$ in soybean meal (Ruiz et al., 2008; Tavernari et al., 2008).

Phytase breaks down the insoluble complexes of phytic acid, releasing phosphorus, minerals, proteins, amino acids, and starch, therefore allowing their absorption. On the other hand, xylanases act in carbohydrate hydrolysis of the plant cell wall, releasing starch and encapsulated lipids or nutrients that were captured by the viscosity of the NSPs during their passage through the broiler's gut, improving the action of the endogenous enzymes on these nutrients (Cowieson, 2005; Francesch \& Geraert, 2009).

Studies have suggested that the association between phytase and carbohydrases can have an additive effect (Cowieson \& Adeola, 2005; Schramm et al., 2017) because the efficiency of the phytase added to the diet can be reduced by restricted access to the substrate in the presence of NPSs. Similarly, the absence or insufficiency of phytase could reduce the action of carbohydrases on nutrients that may be complexed into the phytate molecule (Olukosi et al., 2007).

Phytase supplementation in an isolated manner allows the reduction of crude protein and minerals, such as phosphorus, calcium, and sodium, in diets without compromising broiler performance (Lelis et al, 2010; Donato et al., 2011; Meneghetti et al., 2011). Although the reduction of nutrients is possible because of the higher metabolizability provided by the enzyme, calcium should be reduced proportionally to reduce the total phosphorus levels to avoid an increase in intestinal $\mathrm{pH}$ due to formation of calcium phytate and its interaction with iron, magnesium, and zinc and a reduction in phytase activity by high calcium concentrations (Schoulten et al., 2003). Similarly, high sodium concentrations may interact with phytate by making endogenous amino 
acids unavailable and reducing the effect of phytase (Cowieson et al., 2011).

Studies show that the inclusion of xylanase could reduce the metabolizable energy level by up to $0.419 \mathrm{MJ} / \mathrm{kg}$ in diets, not changing broiler's performance compared to diets without enzymes that meet the requirement of metabolizable energy because xylanase can increase the metabolizability of energy (Nian et al., 2011; Stefanello et al., 2016).

Thus, new research should be carried out to evaluate the association between xylanase and phytase enzymes on metabolizable energy levels in broiler diets, because of the individual action of each enzyme that could increase the reduction of energy levels in diets.

Therefore, the objective of this study was to evaluate the inclusion of phytase and xylanase in broiler diets with reduction of metabolizable energy, phosphorus, calcium, and sodium on the metabolizability coefficients of nutrients and the metabolizable energy of diets in the initial period of rearing.

\section{Material and Methods}

The study was conducted at the Experimental Laboratory in Avian Science of the Faculty of Veterinary Medicine and Animal Science of the Federal University of Mato Grosso do Sul, under the approval of the Committee on Ethics in the Use of Animals (CEUA/UFMS), protocol number 737/2015.

A total of 250 one-day-old male broilers of Cobb 500 lineage were distributed among a completely randomized design with five treatments and five replicates of 10 broilers per experimental unit. The broilers were standardized by weight $( \pm 10 \%$ of the average weight of the experimental unit) so that all experimental units had similar weights.

Broilers were housed in twenty-five $2.5 \mathrm{~m}^{2}$ cages in a conventional shed with fiber-cement roofing and earthen floor. Wood shavings (untreated wood chips) were used as bedding material; the bed was considered new, as it had not been used previously. Cages were equipped with brood heaters, trough feeders and automatic poultry drinkers. Feed and water were provided ad libitum. The lighting program adopted was $24 \mathrm{~h}$ of light (natural + artificial) daily.

Thermal conditions in the poultry house were monitored using a temperature and humidity sensor at $07 \mathrm{~h} 00$ and $17 \mathrm{~h} 00$. The following mean values were obtained: average temperature: $24.5^{\circ} \mathrm{C}$, minimum temperature: $20.8 \pm 0.7^{\circ} \mathrm{C}$, maximum temperature: $28.3 \pm 0.9^{\circ} \mathrm{C}$; air relative humidity: $66 \% \pm 7 \%$.

The experimental treatments consisted of a positive control diet fully meeting the nutritional requirements, without phytase or xylanase; a negative control diet with a metabolizable energy (ME) reduction of $0.419 \mathrm{MJ} / \mathrm{kg}$, without phytase or xylanase; and diets with $\mathrm{ME}$ reductions of $0.209,0.419$, and $0.628 \mathrm{MJ} / \mathrm{kg}$, with phytase and xylanase. For all energy-reduced diets, the nutritional matrix of phytase the reductions of $0.15 \% \mathrm{P}, 0165 \% \mathrm{Ca}$ and $0.035 \% \mathrm{Na}$ were considered.

The phytase used in the experiment was derived from the microorganism Escherichia coli, 
while xylanase was derived from Tricoderma reesei. Their respective inclusion levels were fixed at $75 \mathrm{~g} / \mathrm{t}$ (500 FTU/kg) and $100 \mathrm{~g} / \mathrm{t}$ (16000 BXU/kg). Both enzymes were acquired from commercial enterprises.

Experimental diets were based on corn and soybean meal and were formulated to meet the nutritional requirements of broilers as proposed by Rostagno et al. (2011) (Table 1) except for metabolizable energy, available phosphorus, calcium, and sodium.

The metabolizability trial started on the $14^{\text {th }}$ day of age and consisted of three days of adaptation to the experimental diets and five days of partial collection of excreta. Titanium dioxide $\left(\mathrm{TiO}_{2}\right)$ was used as an indicator with the inclusion of $0.5 \%$ in substitution of inert in the experimental diets.

For the collection of excreta, in each experimental unit, the bed of the boxes was completely covered by double-sided canvas $(150 \mu \mathrm{m})$ to avoid bed entry and contamination of the samples. Excreta were collected twice a day ( 8 and $16 \mathrm{~h})$, to avoid fermentation, by scraping, discarding diet residues, feathers or any contaminating material. At each collection time, the canvas with excreta were replaced by clean canvas and the samples were placed in plastic bags previously identified and stored in a freezer $\left(-10^{\circ} \mathrm{C}\right)$ until the end of the collection period.

Table 1. Percentage composition and calculated values of the experimental diets for broilers in the initial phase (8 to 21 days of age)

\begin{tabular}{|c|c|c|c|c|c|}
\hline \multirow{2}{*}{ Ingredients, $\mathrm{g} / \mathrm{kg}$} & \multirow{2}{*}{$\begin{array}{l}\text { Positive } \\
\text { control }\end{array}$} & \multirow{2}{*}{$\begin{array}{l}\text { Negative } \\
\text { control }\end{array}$} & \multicolumn{3}{|c|}{$\begin{array}{l}\text { Reduction of metabolizable energy } \\
(\mathrm{MJ} / \mathrm{kg}) \text { with phytase and xylanase }\end{array}$} \\
\hline & & & 0.209 & 0.419 & 0.628 \\
\hline Corn, $7,88 \%$ & 581.6 & 581.6 & 581.6 & 581.6 & 581.6 \\
\hline Soybean meal, $46 \%$ & 347.5 & 347.5 & 347.5 & 347.5 & 347.5 \\
\hline Soy oil & 26.2 & 14.8 & 20.5 & 1,48 & 0,91 \\
\hline Dicalcium phosphate & 14.9 & 6.7 & 6.7 & 6.7 & 6.7 \\
\hline Calcitic limestone & 9.1 & 10.1 & 10.1 & 10.1 & 10.1 \\
\hline Common salt & 5.0 & 3.9 & 3.9 & 3.9 & 3.9 \\
\hline Min-vit ${ }^{1}$ supplement & 4.0 & 4.0 & 4.0 & 4.0 & 4.0 \\
\hline DL- Methionine & 3.1 & 3.1 & 0,31 & 0,31 & 0,31 \\
\hline L- Lysine $\mathrm{HCl}$ & 2.7 & 2.7 & 2.7 & 2.7 & 2.7 \\
\hline L- Threonine & 0.8 & 0.8 & 0.8 & 0.8 & 0.8 \\
\hline Inert & 5.2 & 24.7 & 18.8 & 24.5 & 30.2 \\
\hline Xylanase & 0.0 & 0.0 & 0.1 & 0.1 & 0.1 \\
\hline \multirow[t]{2}{*}{ Phytase } & 0.000 & 0.000 & 0.075 & 0.075 & 0.075 \\
\hline & \multicolumn{5}{|c|}{ Calculated values } \\
\hline $\begin{array}{l}\text { Metabolizable energy } \\
(\mathrm{MJ} / \mathrm{kg})\end{array}$ & 12.77 & 12.35 & 12.56 & 12.35 & 12.14 \\
\hline Crude protein, $\mathrm{g} / \mathrm{kg}$ & 212.0 & 212.0 & 212.0 & 212.0 & 212.0 \\
\hline Arginine dig., g/kg & 13.1 & 13.1 & 13.1 & 13.1 & 13.1 \\
\hline Lysine dig., g/kg & 12.2 & 12.2 & 12.2 & 12.2 & 12.2 \\
\hline $\begin{array}{l}\text { Methionine+cystine } \\
\text { dig., } \mathrm{g} / \mathrm{kg}\end{array}$ & 8.9 & 8.9 & 8.9 & 8.9 & 8.9 \\
\hline Threonine dig., g/kg & 7.9 & 7.9 & 7.9 & 7.9 & 7.9 \\
\hline
\end{tabular}


Tryptophan dig., g/kg

Calcium, g/kg

Potassium, g/kg

Phosphorus disp., g/kg

Chlorine, $\mathrm{g} / \mathrm{kg}$

Sodium, g/kg

\section{4}

8.4

8.1

4.0

3.3

2.1

2.4

6.8

8.1

2.5

2.7

1.7 2020, Vol. 8, No. 3

${ }^{1}$ Levels per $\mathrm{kg}$ of diet of the initial mineral-vitamin supplement: $450.75 \mathrm{~g}$ methionine; $65.25 \mathrm{~g}$ choline; 2,750,000 IU Vitamin A; 500,000 IU Vitamin D3; 4,000 IU Vitamin E; 375 mg Vitamin K3; $300 \mathrm{mg}$ Vitamin B1; 1,125 mg Vitamin B2; $500 \mathrm{mg}$ Vitamin B6; 4,000 mcg Vitamin B12; 8,750 mg Niacin; 2,300 mg Pantothenic Acid; $100 \mathrm{mg}$ Folic Acid; $15 \mathrm{mg}$ Biotin; 7,500 mg Iron; 2,250 mg Copper; 15 g Manganese; $15 \mathrm{~g}$ Zinc; $250 \mathrm{mg}$ Iodine; $62.5 \mathrm{mg}$ Selenium; 2500 mg Avilamycin; $10 \mathrm{~g}$ Nicarbazin; 3,750 mg Senduramycin.

Subsequently, the corresponding samples from each experimental unit were homogenized and two aliquots $( \pm 800 \mathrm{~g})$ were taken for analysis. The samples were submitted to pre-drying in a forced ventilation oven $\left(55^{\circ} \mathrm{C}\right)$ for $72 \mathrm{~h}$ and processed in a ball mill to analyse the contents of dry matter, nitrogen, phosphorus, and ethereal extract (Silva \& Queiroz, 2006). Crude energy was determined by burning the sample in a calorimetric pump.

The metabolizability coefficients of dry matter (DMMC), phosphorus (PMC), crude protein (CPMC), ethereal extract (EEMC), apparent metabolizable energy (AME), corrected apparent metabolizable energy for nitrogen retention (AMEn) of excreta, and retention of nitrogen per day were determined. Nutrient metabolizability (partial excreta collection method) was calculated using the titanium indigestibility factor, used as an indicator, by the formulas:

Excreta indigestibility factor (IF):

$\mathrm{IF}=\left[\mathrm{TiO}_{2}\right]$ of the diet $/\left[\mathrm{TiO}_{2}\right]$ of the sample (excreta);

In which: $\left[\mathrm{TiO}_{2}\right]$ concentration of titanium dioxide;

Metabolizability coefficient (MC):

$\mathrm{MC}=(\%$ of the nutrient in the diet $)-(\%$ of the nutrient in excreta $\times \mathrm{IF}) /(\%$ of the nutrient in the diet)

In which: IF corresponds to the excreta indigestibility factor;

AME and AMEn values were determined by the formulas:

$\operatorname{AME}(\mathrm{MJ} / \mathrm{kg}$ of dry matter $)=\mathrm{EB}$ of the diet $-(\mathrm{EB}$ of excreta $*$ IF of excreta $)$;

AMEn $(\mathrm{MJ} / \mathrm{kg}$ of dry matter $)=\mathrm{EB}$ of the diet $-[(\mathrm{EB}$ of excreta $*$ IF of excreta $)+8.22 *$ (NB)];

$\mathrm{NB}=$ nitrogen balance $=\mathrm{N}$ of the diet $-(\mathrm{N}$ of excreta $*$ IF of excreta $)$.

The data were submitted to an analysis of variance (ANOVA) and the means were compared by the Tukey test, as well as by orthogonal contrasts using the Scheffer test, both at the 5\% probability level. The analyses were performed using the SAS statistical program (University 
version). The contrasts tested were:

C1-treatment with reduction of $0.419 \mathrm{MJ} / \mathrm{kg}$ of $\mathrm{ME}$, phosphorus, calcium and sodium, with phytase and xylanase versus treatment with reduction of $0.419 \mathrm{MJ} / \mathrm{kg}$ of $\mathrm{ME}$, phosphorus, calcium, and sodium, without phytase and xylanase, indicating the effect of enzymatic supplementation on the reduction of $0.419 \mathrm{MJ} / \mathrm{kg}$ of ME;

$\mathrm{C} 2$ - positive control versus other treatments, which demonstrated the effect of the reduction of ME, phosphorus, calcium, and sodium in relation to the positive control diet;

C3 - positive control versus treatments with reductions of $0.209,0.419$, and $0.628 \mathrm{MJ} / \mathrm{kg}$ of ME, phosphorus, calcium, and sodium, with phytase and xylanase, indicating the effect of the reduction of $\mathrm{ME}$, its nutritional adjustments and the enzymatic supplementation in relation to the diet positive control.

\section{Results}

Reduction of metabolizable energy, phosphorus, calcium, and sodium, associated with inclusion of phytase and xylanase, influenced $(\mathrm{P}<0.05)$ the nutritional metabolizability coefficients of broiler diets at 21 days (Table 2).

In diets containing 12.56 and $12.14 \mathrm{MJ} / \mathrm{kg}$ the use of the enzymes increased $(\mathrm{P}<0.05)$ the DMMC. The positive control diet obtained the worst $(\mathrm{P}<0.05)$ DMMC. Conversely, broilers fed with $12.35 \mathrm{MJ} / \mathrm{kg}$ of $\mathrm{ME}$, with and without supplementation of enzymes, presented intermediate values for this coefficient.

Table 2. Nutrient metabolizability coefficients and apparent metabolizable energy (AME) contents, corrected apparent metabolizable energy for nitrogen retention (AMEn), and nitrogen balance (NB) of diets for 21-day age broilers

\begin{tabular}{|c|c|c|c|c|c|c|c|}
\hline \multirow{2}{*}{$\begin{array}{l}\text { Metabolizable } \\
\text { energy in diets } \\
(\mathrm{MJ} / \mathrm{kg})\end{array}$} & \multirow[b]{2}{*}{ Enzymes } & \multicolumn{6}{|c|}{ Variables $^{1}$} \\
\hline & & $\begin{array}{c}\text { DMMC } \\
(\%) \\
\end{array}$ & $\begin{array}{l}\text { PMC } \\
(\%) \\
\end{array}$ & $\begin{array}{c}\text { CPMC } \\
(\%) \\
\end{array}$ & $\begin{array}{c}\mathrm{AME} \\
(\mathrm{MJ} / \mathrm{kg}) \\
\end{array}$ & $\begin{array}{l}\text { AMEn } \\
(\mathrm{MJ} / \mathrm{kg})\end{array}$ & $\begin{array}{c}\mathrm{NB} \\
\text { (g/day) }\end{array}$ \\
\hline $12.77^{*}$ & Without & $52.19 \mathrm{c}$ & $27.97 \mathrm{~b}$ & $52.82 \mathrm{c}$ & $13.56 \mathrm{abc}$ & $12.87 \mathrm{ab}$ & 1.69 \\
\hline $12.35^{* *}$ & Without & $55.41 \mathrm{~b}$ & $26.34 b$ & $52.49 \mathrm{c}$ & $13.34 \mathrm{c}$ & $12.66 \mathrm{~b}$ & 1.42 \\
\hline 12.56 & With & $60.36 \mathrm{a}$ & $43.04 \mathrm{a}$ & $57.23 \mathrm{ab}$ & $13.92 \mathrm{a}$ & $13.15 \mathrm{a}$ & 1.60 \\
\hline 12.35 & With & $56.78 \mathrm{~b}$ & $41.0 \mathrm{a}$ & $55.02 \mathrm{bc}$ & $13.45 \mathrm{bc}$ & $12.71 b$ & 1.54 \\
\hline 12.14 & With & $60.70 \mathrm{a}$ & $45.13 \mathrm{a}$ & $59.59 a$ & $13.78 \mathrm{ab}$ & $12.97 \mathrm{ab}$ & 1.69 \\
\hline Mean & & 57.08 & 36.69 & 55.43 & 3251.13 & 3073.85 & 1.59 \\
\hline $\mathrm{CV}(\%)^{3}$ & & 2.89 & 7.09 & 3.98 & 1.69 & 1.62 & 1.59 \\
\hline \multirow[t]{2}{*}{$P$-value $e^{4}$} & & $<0.001$ & $<0.001$ & 0.001 & 0.004 & 0.009 & 0.400 \\
\hline & & \multicolumn{6}{|c|}{ Orthogonal contrast $^{2}$} \\
\hline $\mathrm{C} 1$ & & 0.203 & $<0.001$ & 0.084 & 0.477 & 0.729 & 0.574 \\
\hline
\end{tabular}




\begin{tabular}{lllllll} 
C3 & $<0.001$ & $<0.001$ & 0.008 & 0.627 & 0.987 & 0.663 \\
C3 & $<0.001$ & $<0.001$ & 0.001 & 0.221 & 0.512 & 0.578 \\
\hline
\end{tabular}

*Reduction of $0 \mathrm{MJ} / \mathrm{kg}$ - positive control; **Reduction of $0.419 \mathrm{MJ} / \mathrm{kg}$ without enzymes negative control;

${ }^{1}$ DMMC: dry matter metabolizability coefficient; PMC: phosphorus metabolizability coefficient; CPMC: crude protein metabolizability coefficient;

${ }^{2} \mathrm{C} 1: 12.35 \mathrm{MJ} / \mathrm{kg}$ with phytase and xylanase $\times 12.35 \mathrm{MJ} / \mathrm{kg}$ without phytase and xylanase; $\mathrm{C} 2$ : positive control $\mathrm{x}$ other treatments; $\mathrm{C} 3$ : positive control diet $\mathrm{x}$ diet 12.56, 12.35, and $12.14 \mathrm{MJ} / \mathrm{kg}$ with reduction $\mathrm{P}, \mathrm{Ca}$ and $\mathrm{Na}$ with phytase and xylanase;

${ }^{3} \mathrm{CV}=$ coefficient of variation; ${ }^{4}$ Means followed by distinct letters in the column differ by the Tukey test $(\mathrm{P}<0.05) ;{ }^{3} \mathrm{P}<0.05$ is significant by the Scheffer test.

Regarding the contrasts, reductions of metabolizable energy, phosphorus, calcium, and sodium improved $(\mathrm{P}<0.05)$ DMMC by $11.7 \%$, compared to the positive control diet $(\mathrm{C} 2$ contrast) and 13.6\% with the inclusion of the enzymes (C3 contrast). All groups fed with enzymatic supplementation, obtained a higher $(\mathrm{P}<0.05) \mathrm{PMC}$ in relation to the diets without enzymatic supplementation (positive control diet and negative control diet)In the present study, there was an effect $(\mathrm{P}<0.05)$ for the $\mathrm{C} 1$ contrast analysis only for $\mathrm{PMC}$, for which a $55.6 \%$ improvement was observed in the diets containing phytase and xylanase with 12.35 $\mathrm{MJ} / \mathrm{kg}$ of metabolizable energy. -Via contrast $\mathrm{C} 2$, the $\mathrm{PMC}$ which improved $(\mathrm{P}<0.05)$ by $39.0 \%$ with reductions of metabolizable energy, phosphorus, calcium, and sodium. Phytase and xylanase supplementation improved PMC $(\mathrm{P}<0.05)$ by $53.9 \%$ (C3 contrast).

The $\mathrm{CPMC}$ was $12.8 \%$ higher $(\mathrm{P}<0.05)$ in diet with $12.14 \mathrm{MJ} / \mathrm{kg}$ of metabolizable energy containing phytase and xylanase compared to the positive control diet. Also, it was $13.5 \%$ higher compared to the negative control diet and did not differ $(\mathrm{P}>0.05)$ from the metabolizability obtained for the diet containing $12.56 \mathrm{MJ} / \mathrm{kg}$ of metabolizable energy and enzymes and adjusted nutritionally. The CPMC of the diet containing $12.35 \mathrm{MJ} / \mathrm{kg}$ of metabolizable energy was intermediate in relation to the other diets. Regarding the contrasts, reductions of metabolizable energy, phosphorus, calcium, and sodium (C2 contrast) improved $(\mathrm{P}<0.05) \mathrm{CPMC}$ by $6.2 \%$. Phytase and xylanase supplementation improved the crude protein metabolizability by $8.4 \%$ (C3 contrast). The AME and AMEn values from diets with 12.56 $\mathrm{MJ} / \mathrm{kg}$ of metabolizable energy containing enzymes and nutritionally adjusted were higher $(\mathrm{P}<0.05)$ compared to that of the other diets and were similar $(\mathrm{P}>0.05)$ to the positive control diet and the diet with $12.14 \mathrm{MJ} / \mathrm{kg}$ of metabolizable energy containing enzymes. AME and AMEn values of the positive control diet did not differ $(\mathrm{P}>0.05)$ from the values of the diet with $12.35 \mathrm{MJ} / \mathrm{kg}$ containing enzymes.

Despite the positive effect of the energy level reduction of the diet when associated with phytase and xylanase on CPMC, there was no effect $(\mathrm{P}>0.05)$ of the evaluated treatments on nitrogen retention by the broilers.

No significant effects on AME and AMEn values in all tested contrasts $(\mathrm{P}>0.05)$ showed that 
the reduction of metabolizable energy, phosphorus, calcium, and sodium, containing phytase and xylanase, did not affect the energy utilization of the ingredients by broilers and they were identical to those of the positive control treatment.

\section{Discussion}

The results show that in the diets containing -lower $(12.14 \mathrm{MJ} / \mathrm{kg})$ and - higher $(12,56 \mathrm{MJ} / \mathrm{kg})$ metabolizable energy, the use of the enzymes were efficient for nutrient utilization by the better DMMC, because this coefficient reflects nutrient metabolizability and its increase indicates greater absorption (Barbosa et al., 2008). The positive effect of the action of the enzymes, especially phytaseon the absorption and better utilization of phosphorus can be observed by the PMC in all groups fed with enzymatic supplementation.

PMC improvement was caused by the hydrolysis of the phospho-ester bonds of the phytate molecule, mainly in the upper portion of the gastrointestinal tract in the acid medium (proventriculus and gizzard) (Augspurger et al., 2003), composed of sequential reactions of dephosphorylation, producing smaller molecules of myo-inositol phosphate esters and inorganic phosphors suitable for absorption (Bedford \& Partridge, 2010). In addition, as the levels of minerals in the diet decreased, broilers had the capacity to increase the retention of these nutrients for physiological maintenance (Ravindran et al., 2001).

By adding phytase (500 FTU/kg) to the diet containing $12.37 \mathrm{MJ} / \mathrm{kg}$ of metabolizable energy for 25-day-old broilers, Lelis et al. (2010) observed a $29.5 \%$ improvement in the phosphorus metabolizability coefficient compared to the diet with the same energetic level and without added enzymes. Similar results were obtained by Fukayama et al. (2008) when broilers (1- to 20-days-old) were supplemented with phytase (1000 FTU) in diets containing $12.31 \mathrm{MJ} / \mathrm{kg}$ of metabolizable energy compared to balanced diets with $12.56 \mathrm{MJ} / \mathrm{kg}$ of metabolizable energy and without phytase.

In this study, the protein metabolizability was possibly favoured by the reduction of corn and soybean NSPs promoted by xylanase, as well as the hydrolysis of phosphorus-protein/amino acid bonds by phytase, which supports the worst values $(\mathrm{P}<0.05)$ obtained for broilers fed with the positive and negative control diets.

The additive effect of phytase and xylanase on DMMC, CPMC, and AME of broilers was also observed by Schramm et al. (2017) when they added phytase (1,000 FTU/kg) in corn and soybean meal diets containing xylanase $(150 \mathrm{BXU} / \mathrm{kg})$. In addition, the use of enzymatic complexes consisting of carbohydrases can improve protein metabolizability from 3.3 to 7.1\% (Novak et al., 2008; Li et al., 2010), with direct effects on weight gain and efficiency improvements (Yu \& Chung, 2004; Jia et al., 2009).

It is estimated that corn ( $7.9 \%$ crude protein) and soybean meal (46\% crude protein) present approximately 0.18 and $0.38 \%$ of phytophosphorus, respectively (Rostagno et al., 2017). However, CPMC increases can be mainly attributed to the reduction of energy expenditure during digestion, with the production of endogenous amino acids, thus providing more energy for other metabolic processes. 
The higher AME and AMEn values resulting from diets with $12.56 \mathrm{MJ} / \mathrm{kg}$ metabolizable energy containing enzymes and nutritionally adjusted is possibly due to lower nutrient wastage than other diets, which can be confirmed by the highest values obtained from CMMC and CPMC for this treatment.

In relation to the analysis of contrasts, improved metabolizability in DMMC, PMC and CPMC can be attributed to the nutrient utilization efficiency by the broilers. By reducing phosphorus, calcium, sodium, and metabolizable energy, the amount of nutrients may have approached the actual requirement of the broiler, being optimized with the enzymes. It is known that the closer the supply of nutrients to the actual requirement of the broiler, the greater the use of the nutrients. Similar results were also obtained by Cowieson \& Adeola (2005) when evaluating $200 \mathrm{mg}$ of an enzyme complex (200 BXU of xylanase, $400 \mathrm{U}$ of amylase and $4000 \mathrm{U}$ of protease) and $200 \mathrm{mg}$ of phytase (1000 FTU/kg) for broilers in the growth phase.

The significant effect on contrast analysis (C1) for PMC, suggest that there was better use of the phosphorus in the diet with the use of phytase and xylanase, with a possible reduction of environmental impact by the excretion of this mineral, in the diet containing $12.35 \mathrm{MJ} / \mathrm{kg}$ of metabolizable energy was used in the diets.

The lack of effect of the contrasts analyzed for AME and AMEn demonstrated a synergistic action of the enzymes because each enzyme acts on different substrates. In addition, the reduction of energy favoured the enzymatic action, because enzymatic supplementation may not provide an increase in energy and metabolizability of the nutrients in balanced diets (without reducing the energy level) (Barbosa et al., 2014).

\section{Conclusion}

The inclusion of phytase (500 FTU/kg) and xylanase $(16,000 \mathrm{BXU} / \mathrm{kg})$ in the diets of broilers in the initial period of rearing allows the reduction of the metabolizable energy by up to 0.628 $\mathrm{MJ} / \mathrm{kg}, 0.15 \%$ of the available phosphorus, $0.165 \%$ of calcium, and $0.035 \%$ of sodium, and improves the metabolizability of nutrients.

\section{Acknowledgments}

This study was financed in part by the Coordenação de Aperfeiçoamento de Pessoal de Nível Superior - Brasil (CAPES) - Finance Code 001. This study was realized with the support of the Universidade Federal de Mato Grosso do Sul - UFMS/MEC - Brazil.

\section{References}

Augspurger, N. R., Webel, D. M., Lei, X. G., \& Baker, D. H. (2003). Efficacy of an E. coli phytase expressed in yeast for releasing phytate-bound phosphorus in young chicks and pigs. Journal of Animal Science, 81(2), 474-483. https://doi.org/10.2527/2003.812474x

Barbosa, F. J. V., Lopes, J. B., Figuerêdo, A.V., Abreu, L. M. T., Dourado, L. R. B., Farias, L. A., \& Pires, J. E. P. (2008). Metabolizable energy levels in diets for broiler maintained in environment of high temperature. Brazilian Journal of Animal Science, 37(5), 849-855. 
https://doi.org/10.1590/51516-35982008000500011

Barbosa, N. A. A., Bonato, M. A., Sakomura, N. K., Dourado, L. R. B., Fernandes, J. B. K., \& Kawauchi, I. M. (2014). Ileal digestibility of broilers fed diets supplemented with $\begin{array}{llll}\text { exogenous enzymes. } & \text { Comunicata } & \text { Scientiae, } & \text { 5(4), }\end{array}$ https://doi.org/10.14295/cs.v5i4.460

Bedford, M. R., \& Partridge, G. G. (2010). Enzymes in farm animal nutrition. (3rd ed). Cambridge: CABI, 329p.

Cowieson, A. J. (2005). Factors that affect the nutritional value of maize for broilers. Animal Feed Science and Technology, 119(3-4), 293-305. https://doi.org/10.1016/j.anifeedsci.2004.12.017

Cowieson, A. J., \& Adeola, O. (2005). Carbohydrases, protease and phytase have an additive beneficial effect in nutritionally marginal diets for broiler chicks. Poultry Science, 84(12), 1860-1867. https://doi.org/10.1093/ps/84.12.1860

Cowieson, A. J., Bedford, M. R., Ravindran, V., \& Selle, P. H. (2011). Increased dietary sodium chloride concentrations reduce endogenous amino acid flow and influence the physiological response to the ingestion of phytic acid by broiler chickens. British Poultry Science, 52(5), 613-624. https://doi.org/10.1080/00071668.2011.614221

Donato, D. C. Z., Albuquerque, R., Garcia, P. D. S. R., \& Balieiro, J. C. C. (2011). Performance of broilers fed diets with different calcium levels and supplemented with phytase. Brazilian Journal of Animal Science, 40(10), 2161-2166. https://doi.org/10.1590/S1516-35982011001000014

Francesch, M., \& Geraert, P. A. (2009). Enzyme complex containing carbohydrases and phytase improves growth performance and bone mineralization of broilers fed reduced nutrient corn-soybean-based diets. Poultry Science, 88(9), 1915-1924. https://doi.org/10.3382/ps.2009-00073

Fukayama, E. H., Sakomura, N. K., Dourado, L. R. B., Neme, R., Fernandes, J. B. K., \& Marcato, S. M. (2008). Effect of phytase suplementation on performance and nutrient digestibility in diets of broilers. Brazilian Journal of Animal Science, 37(4), 629-635. https://doi.org/10.1590/S1516-35982008000400007

Jia, W., Slominski, B. A., Bruce, H.L., Blank, G., Crow, G., \& Jones, O. (2009). Effects of diet type and enzyme addition on growth performance and gut health of broiler chickens during subclinical. Clostridium perfringens challenge. Poultry Science, 88(1), 132-140. https://doi.org/10.3382/ps,2008-00204

Lelis, G. R., Albino, L. F. T., Silva, C.R., Rostagno, H. S., Gomes, P. C., \& Borsatto, C. G. (2010). Phytase dietetic supplementation on nutrients metabolism of broilers. Brazilian Journal of Animal Science, $\quad 39(8), \quad 1768-1773$. https://doi.org/10.1590/S1516-35982010000800020

Li, Y., Chen, X., Chen, Y., Li, Z., \& Cao, Y. (2010). Effects of $\beta$-mannanase expressed by 
Pichiapastoris in corn-soybean meal diets on broiler performance, nutriente digestibility, energy utilization and immunoglobulin levels. Animal Feed Science and Technology, 159(1-2), 59-67. https://doi.org/10.1016/j.anifeedsci.2010.05.001

Meneguetti, C., Bertechini, A. G., Rodrigues, P. B., Fassani, E. J., Brito, J. A. G., Reis, M. P., \& Garcia Jr, A. A. P. (2011). High levels of phytase in diets for broilers. Brazilian Journal of Veterinary and Animal Sciences, 63(3), 624-632.

https://doi.org/10.1590/S0102-09352011000300014

Nian, F., Guo, Y. M., Ru, Y. J., Li, F. D., \& Péron, A. (2011). Effect of exogenous xylanase supplementation on the performance, net energy and gut microflora of broiler chickens fed wheat-based diets. Asian-Australasian Journal of Animal Sciences, 24(3), 400-406. https://doi.org/10.5713/ajas.2011.10273

Novak, C. L., Yakout, H. M., \& Remus, J. (2008). Response to varying dietary energy and protein with or without enzyme supplementation on leghorn performance and economics. 2. Laying Period. Journal Applied Poultry Research, 17(1), 17-33.

https://doi.org/10.3382/japr.2006-00126

Olukosi, O. A., Cowieson, A. J., \& Adeola, O. (2007). Age-related influence of a cocktail of xylanase, amylase, and protease or phytase individually or in combination in broilers. Poultry Science, 86(1), 77-86. https://doi.org/10.1093/ps/86.1.77

Ravindran, V., Selle, P. H., Ravindran, G., Morel, P. C. H., Kies, A. K., \& Bryden, W. L. (2001). Microbial phytase improves performance, apparent metabolizable energy, and ileal amino acid digestibility of broilers fed a lysine-deficient diet. Poultry Science, 80(3), 338-344. https://doi.org/10.1093/ps/80.3.338

Rostagno, H. S., Albino, L. F. T., Hannas, M. I., Donzele, J. L., Sakomura, N. K., Perazzo, F. G., ... Brito, C. O. (2017). Brazilian tables for poultry and swine (food composition and nutritional requirements. (4rd ed). Viçosa, MG: Editora UFV, 488p.

Rostagno, H. S., Albino, L. F. T., Donzele, J. L., Gomes, P. C., Oliveira, R. F., Lopes, D. C., ... Euclides, R. F. (2011). Brazilian tables for poultry and swine (food composition and nutritional requirements). (3rd ed). Viçosa, MG: Editora UFV, 235p.

Ruiz, U. S., Thomaz, M. C., Hannas, M. I., Fraga, A. L., Watanabe, P. H., \& Silva, S. Z. (2008). Enzyme complex for swine: nutrient digestion, metabolism, performance and environmental impact. Brazilian Journal of Animal Science, 37(3), 458-468. https://doi.org/10.1590/S1516-35982008000300011

Schoulten, N. A., Teixeira, A. S., Freitas, R. T. F., Bertechini, A. G., Conte, A. J., \& Silva, H. O. (2003). Levels of calcium in broiler diets supplemented with phytase in the initial phase. Brazilian Journal of Animal Science, 32(5), 1190-1197.

https://doi.org/10.1590/S1516-35982003000500020

Schramm, V. G., Durau, J. F., Barrilli, L. N. E., Sobara, J. O. B., Cowieson, A. J., Féliz, A. P., \& Maiorka, A. (2017). Interaction between xylanase and phytase on the digestibility of corn 


\section{Macrothink}

Journal of Agricultural Studies

ISSN 2166-0379 2020, Vol. 8, No. 3

and a corn/soy diet for broiler chickens. Poultry Science, 96(5), 1204-1211. https://doi.org/10.3382/ps/pew356

Silva, D. J., \& Queiroz, A. C. (2006). Food analysis: chemical and biological methods. (3rd ed). Viçosa: UFV, 235p.

Stefanello, C., Vieira, S. L., Carvalho, O. S., Sorbara, J. O. B., \& Cowieson, A. J. (2016). Energy and nutrient utilization of broiler chickens fed corn-soybean meal and corn-based diets supplemented with xilanase. Poultry Science, 95(8), 1881-1887.

https://doi.org/10.3382/ps/pew070

Tavernari, F. C., Carvalho, T. A., Assis, A. P., \& Lima, H. J. D. (2008). Non-starch polysaccharides soluble in the diet of pigs and poultry. Nutritime, 5(5), 673-689.

Yu, B., \& Chung, T. K. (2004). Effects of multiple-enzyme mixtures on growth performance of broilers fed corn-soybean meals diets. The Journal Applied Poultry Research, 13(2), 178-182. https://doi.org/10.1093/japr/13.2.178

\section{Copyright Disclaimer}

Copyright for this article is retained by the author(s), with first publication rights granted to the journal.

This is an open-access article distributed under the terms and conditions of the Creative Commons Attribution license (http://creativecommons.org/licenses/by/4.0/). 